DOI: $10.7819 /$ rbgn.v15i49.1585

Subject Area: Organizational Strategy and Behavior

\title{
Isomorphism and Institutional Control in a Modular Plant of the Automotive Industry
}

\author{
Isomorfismo e Controle Institucional em uma Planta Modular da Indústria \\ Automobilística
}

\section{Isomorfismo Institucionaly Control en una Planta Modular de la Industria Automotriz}

\author{
Mário Sacomano Neto \\ Oswaldo Mário Serra Truzzi \\ Charles Kirschbaum ${ }^{3}$
}

Received on March 13, 2013 / Accepted on November 14, 2013

Responsible Editor: João Maurício Gama Boaventura, Dr.

Evaluation Process: Double Blind Review

\begin{abstract}
Several studies have addressed how forms of coordination are conditioned by social mechanisms such as trust, reciprocity, control, cooperation and copying. This level of analysis is a critique of the utilitarian tradition, which assumes economic behavior is only minimally affected by relationships and social structure. On the other hand, from the institutional perspective and in economic sociology, economic behavior is embedded in social relations, in which control, isomorphism and the homogeneity of organizational forms are present. In this sense, this article examines how isomorphism (mimetic,
\end{abstract}

normative and coercive) and the ability to control support a cohesive and stable coordinating structure in a modular plant belonging to the automotive industry. By combining isomorphism and control, we combine two institutional field perspectives that are different but complementary: 1) the first field perspective, understood as the total number of relevant actors, where shared meanings are built; and 2) the second field perspective, understood as an institutional sphere of interests which includes power struggles. Research is exploratory, descriptive, based on case studies and interviews with the automaker's production director and with another two

1. Doctor in Production Engineering by the Federal University of São Carlos (UFSCar). [msacomano@ufscar.br]

2. Doctor in Social Sciences by the Federal University of Campinas (Unicamp) Professor at the Federal University of São Carlos ((UFSCar). [truzzi@ufscar.br] Authors' address: Jardim Guanabara - CEP 13565-905 - São Carlos - SP - Brazil

3. Doctor in Business Management by the Getúlio Vargas Foundation (FGV/SP) Professor at the Teaching and Research Institute (Insper) and associate researcher at CEM-Cebrap. [CharlesK1@insper.edu.br] Author's address: Rua Quatá, 300, Vila Olímpia - CEP 04546-042 - São Paulo - SP - Brazil 
modular suppliers' production directors. Some research results show how the automaker employs highly institutionalized mechanisms and routines that are capable of controlling and homogenizing the behavior and performance of parts suppliers. These mechanisms are not limited merely to the formal aspects of relationships, but also to its informal aspects (relationships, trust, rules, etc), capable of institutionalizing various production practices and of stabilizing relationships within the coordination of plant activities. The article points to the paradox of the socially embedded agency, to control and to homogeneity present in interorganizational relationships. The article also contributes to the understanding of how socially embedded aspects are present in coordination processes between companies.

Keywords: Institutional isomorphism. Fields. Control. Interorganizational networks and relationships.

\section{RESUMO}

Diversos estudos têm abordado como as formas de coordenação são condicionadas por mecanismos sociais, como confiança, reciprocidade, controle, cooperação e cópia. Esse nível de análise é uma crítica à tradição utilitarista, que pressupóe o comportamento econômico minimamente afetado pelos relacionamentos e pela estrutura social. Em contrapartida, na perspectiva institucional e na sociologia econômica, o comportamento econômico está imerso nas relaçôes sociais, em que estão presentes o controle, o isomorfismo e a homogeneidade das formas organizacionais. Nesse sentido, este artigo analisa como o isomorfismo (mimético, normativo e coercitivo) e a capacidade de controle suportam uma estrutura de coordenação coesa e estável entre as empresas de uma planta modular da indústria automotiva. Ao conciliar o isomorfismo e o controle, combinamse duas perspectivas institucionais de campo, distintas, porém complementares: 1) a primeira perspectiva de campo, entendida como a totalidade dos atores relevantes, em que se constroem significados comuns; e 2) a segunda perspectiva de campo, entendida como uma esfera institucional de interesses com disputas de poder. A pesquisa é de natureza exploratória, descritiva, baseada em estudo de caso e entrevistas com o diretor de produção da montadora e com outros dois diretores de produção dos fornecedores modulistas.

Alguns resultados da pesquisa mostram como a montadora emprega mecanismos e rotinas altamente institucionalizadas, capazes de controlar e homogeneizar o comportamento e o desempenho dos fornecedores de autopeças. Esses mecanismos não se limitam tão somente aos aspectos formais das relações, mas também aos aspectos informais (relações, confiança, normas etc.), capazes de institucionalizar diversas das práticas produtivas e de estabilizar as relaçôes na coordenação das atividades da planta. $\mathrm{O}$ artigo lança a atenção para o paradoxo da agência socialmente imersa, o controle e a homogeneidade presente nas relaçôes interorganizacionais. $\mathrm{O}$ artigo também contribui para o entendimento de como os aspectos socialmente imersos estáo presentes nos processos de coordenação entre as empresas.

Palavras-chave: Isomorfismo institucional. Campos. Controle. Redes e relaçóes interorganizacionais.

\section{RESUMEN}

Varios estudios han abordado cómo las formas de coordinación están condicionadas por mecanismos sociales, tales como la confianza, la reciprocidad, el control, la cooperación y la copia. Este nivel de análisis es una crítica de la tradición utilitarista, que asume el comportamiento económico mínimamente afectado por las relaciones y la estructura social. Pero el punto de vista institucional y en la sociología económica, el comportamiento económico está inmerso en los sistemas concretos de las relaciones sociales en curso, que son el control de la actualidad, el isomorfismo y la homogeneidad de las formas de organización. Este artículo examina el isomorfismo y la capacidad para soportar una estructura de control para coordinar la planta modular cohesiva y estable. Al combinar el isomorfismo y el control, se combinan dos perspectivas distintas sobre el terreno institucional, pero complementarios: 
1) el terreno como la totalidad de los actores relevantes en la construcción de significados compartidos y 2 de campo) como una esfera de interés en la lucha de poder institucional. La investigación es exploratoria, descriptiva, basada en estudio de caso y entrevistas con el director y montador de producción con dos proveedores de otros directores de producción modulistas. Algunos resultados de la encuesta muestran cómo la automotriz emplea mecanismos altamente institucionalizados y rutinas capaces de controlar y homogeneizar el comportamiento y desempeño de los proveedores de piezas. Estos mecanismos no se limitan sólo a los aspectos formales de la relación, sino también a los aspectos informales (relaciones, la confianza, las normas, etc.) regalos, capaces de institucionalizar las prácticas de producción que disponen y estabilizan las relaciones en la coordinación de las actividades de producción de la planta. El artículo parte de la atención sobre la paradoja de la agencia socialmente inmersa, control y homogeneidad en las relaciones interorganizacionales. El artículo también contribuye a la comprensión de cómo los aspectos integrados socialmente están presentes en los procesos de coordinación entre empresas

Palabras clave: Institucional isomorfismo. Campos. El control. Las redes y las relaciones interorganizacionales.

\section{INTRODUCTION}

Several studies have explored how the market, organizations and economic actors are embedded within the social structure (CASTRO, BALDI, 2010 ; DIMAGGIO, POWELL, 2005; GNYAWALI, MADHAVAN, 2001; GRANOVETTER, 2009; SMELSER, SWEDBERG, 1994; UZZI, 1997; ZUKIN, DIMAGGIO, 1990). This level of analysis is a critique of the utilitarian tradition of economics, which assumes economic behavior is only minimally affected by relationships and social structure. Unlike this utilitarian view, economic actors are embedded in concrete systems of continuous social relationships (GRANOVETTER, 2009).

This social structure, in turn, involves several coordination mechanisms and other components present in economic trades. In the context of relationships between organizations, embeddedness established as the behavior of an organization is determined by the set of its relationships with other organizations. This embedded conception of economic actors has been the topic of several recent studies about networks and fields in Brazil (GOMES, VIEIRA, 2009; GUARIDO FILHO, MACHADO-DASILVA, 2010; VALE, GUIMARÃES, 2010; VASCONCELOS, 2004) and abroad (Fligstein, 2009; LIN et al, 2009; MAINELA, PUHAKKA, 2008; YAMIN, ANDERSON, 2011).

Within the scope of social theory there is an intense debate about the nature of economic action and the relationship of choices with the agency or social structure. Part of the motivation to understand the relationship between economic action and social structure is the work of Granovetter (2009). To the author, economic actors do not decide as independent atoms, neither do they fully adhere to implicit rules, disregarding their own interests. To Granovetter (2009), actors have choices, but within a limited set of constraints imposed by the social structure. This level of analysis of embeddedness is a critique by Granovetter (2009) of the atomized visions of both New Institutional Economics (undersocialized vision) and Social Anthropology (supersocialized vision).

This characteristic of the economic actor mentioned by Granovetter (2009) was supplemented by Zukin and DiMaggio (1990), when they established the economic actor as limited and embedded by structural, cultural, political and cognitive constraints. The political perspective considers the institutional limits of economic power and of incentives; the cognitive observes the processes of mental structure within 
the economic logic; the cultural considers that beliefs and values support economic action (UZZI, 1996); and, finally, structural embeddedness focused on the quality of the relationship and the structure of the connections between actors. This political and social conception of economic reality confirms Abramovay's statement (2001) about the market, characterized by the author as an institution and not a neutral meeting place for buyers and sellers. Organizations in the market are subject to the action and the control of other more powerful organizations and also to institutional isomorphic processes. This embedded vision is also supported by various approaches, such as Social Network Analysis, Institutional Theory and Economic Sociology. These approaches agree that organizational changes are influenced by the social structure and not only by rational decisions associated with efficiency.

In the same line of thought, Fligstein (1996) makes use of the "markets as policies" metaphor and proposes a sociological vision of action within markets, whereby the market is seen as a social structure. The metaphor is divided into two dimensions: in the first, States are seen as the creators of institutional conditions, so that markets are stable. The second dimension involves the performance of companies through various mechanisms to control the market. The goal of these mechanisms is to control the sources of instability in the markets. Property rights, governance structures and rules of interaction are arenas in which the modern state establishes behavioral rules for economic actors. This study, however, not only embodies states as responsible for establishing rules of conduct, but also businesses. Stable markets reflect hierarchical positions that define active and challenging companies. Market leaders force the market's social order and indicate how to deal with crises. Thus, embedded organizations are subject to the interference and control of more powerful actors and isomorphic processes. These types of embeddedness also affect relationships and control structures between companies.
By adopting isomorphism and control as categories of analysis, this study explores the duality between the structure and the agency in trade relationships. The structure generates the homogeneity and isomorphism of the organizational forms (DIMAGGIO, POWELL, 2005), and the agency appears due to the presence of skilled actors who are able to convince other actors to adopt the same shared meanings (FLIGSTEIN, 2009). This article explores isomorphism and social skills as constitutive and complementary elements within trade relationships. Thus, it explores the political and structural aspects of embeddedness (ZUKIN, DIMAGGIO, 1990). Also, when joining isomorphism and control, we combined two distinct, but complementary, institutional field perspectives, as pointed out by Machado-da-Silva, Guarido Filho and Rossoni (2010). Isomorphism seeks to understand how organizations become similar (DIMAGGIO, POWELL, 1991) and the perspective of control seeks to understand how actors are able to induce cooperation with other actors, with the aim of producing and reproducing a set of rules and stabilizing a set of relationships (FLIGSTEIN, 2009). Thus, contracts, cooperation, cooptation, relationships of reciprocity, trust, control and copying, amongst other various mechanisms, are elements of stability and/or control in a particular field. This study thus contributes to the debate about the nature of economic action, sometimes determined by the social structure and sometimes determined by the agency and the capacity of action by actors (ASTLEY, VEN, 2005).

Based on these reflections we formulated the research problem: how do isomorphism and the control capacity generate more stable coordination structures? What is the relationship between dependence, field structuring and isomorphism? How do skilled social actors stabilize relationships in the field? To answer these questions, this article aims at analyzing how isomorphism and control capacity generate stable coordination structures in the relationship between an automaker and its suppliers in a 
modular plant. It also analyzes how adept social actors stabilize relationships with certain actors in a particular field. Thus, organizations, even in an intersubjective way, control and copy and other organizations, to achieve stability in relationships and reduce uncertainty in access to resources in the field (FLIGSTEIN, MCADAM 2012).

From the collection of data, a few propositions were formulated and analyzed in the results. These propositions were made after field observations, as proposed by Eisenhardt (1989). In this way, four propositions were made to support the analysis of the results: 1) "the greater the degree of dependence of one organization on another, more similar it will become to that organization in terms of structure, environment and behavioral focus" (DIMAGGIO, POWELL, 1991, p.76); 2) "the higher the level of structuring of a field, the greater the degree of isomorphism" (DIMAGGIO, POWELL, 1991, p.77); 3) "skilled social actors are key for the emergence of new fields. They must find a way to apply the existing rules and resources in producing local orders by convincing their supporters to cooperate and finding means of accommodation with other groups" (FLIGSTEIN, 2009, p.89); and 4) "skilled social actors from responsible groups, in stable fields, use the existing resources and rules to reproduce their power" (FLIGSTEIN, 2009, p. 89).

We strive to discuss the institutional and social mechanisms as complementary to the understanding of economic phenomena and of trade relationships between companies. Moreover, homogeneity, isomorphic processes and control of dominant companies are central to the understanding of these production plants of the automotive sector and other sectors prone to the modularization of operations. With the implementation of new production arrangements, new forms of technical, organizational and productive cooperation have been incorporated, implying new inter-organizational control mechanisms and routines which are capable of ensuring the stability of relationships.

\section{INSTITUTIONAL ISOMORPHISM AND CONTROL CAPACITY}

In this topic the central concepts of isomorphism and control in the field are presented. The field concept allows us to study at the organizational and societal level, involving complex interrelationships between environments, material and institutional resources (MACHADO-DA-SILVA, GUARIDO FILHO, ROSSONI, 2010). Also the notion of field involves the capacity for political action by powerful actors, capable of stabilizing a set of relationships in favor of their own interests (FLIGSTEIN, 2009). Chart 1 illustrates the different types of field analysis perspectives. This study approaches the first perspective, "Field as the totality of relevant actors", by studying isomorphism, and also approaches the penultimate perspective, "Field as the institutional sphere of interests in dispute", by studying the field's control and social skill.

The prospect of control approaches the field vision of Fligstein and McAdam (2012) and Bourdieu (2005) and moves away from the vision of field and isomorphism of Powell and DiMaggio (SWEDBERG, 2004). In the same line of thought as Bourdieu (2005) and Fligstein and McAdam (2012), control and power are central themes, whereas, in DiMaggio and Powell's (2005) perspective of isomorphism, the central issue is homogeneity. In the isomorphic perspective, "rational actors make their organizations increasingly similar as they try to transform them" (DIMAGGIO, POWELL, 1991, p.74).

The combination of these two perspectives offers a debate regarding voluntaristic and deterministic organizational theories presented by Ven and Astley (2005). The perspective of control is similar to the voluntaristic concept, by establishing the social actor's capacity for action. In the isomorphism perspective, on the other hand, the institutional environment is deterministic for the organizational forms and the result is a process that makes organizations similar. But it is less clear who exercises agency (HIRSCH, 1997). However, there are already efforts to reconcile these two points of view, as highlighted by Hirsch (2008). 


\begin{tabular}{|c|c|c|c|}
\hline $\begin{array}{l}\text { Theoretical } \\
\text { Perspective }\end{array}$ & Authors & Key elements & Description \\
\hline $\begin{array}{l}\text { Field as the } \\
\text { totality of relevant } \\
\text { actors }\end{array}$ & $\begin{array}{l}\text { DiMaggio; } \\
\text { Powell. }\end{array}$ & $\begin{array}{l}\text { Meaning and } \\
\text { Relationships }\end{array}$ & $\begin{array}{l}\text { Organizations that share common meaning systems and which interact more } \\
\text { frequently with each other than with actors outside the field, thus making up a } \\
\text { recognized field of institutional life. }\end{array}$ \\
\hline $\begin{array}{l}\text { Field as } \\
\text { functionally } \\
\text { specific arena }\end{array}$ & Scott; Meyer. & Social Function & $\begin{array}{l}\text { Similar and dissimilar, interdependent organizations, operating in a functionally } \\
\text { specific arena, understood technically and institutionally, with their trade } \\
\text { partners, funding sources and regulators. }\end{array}$ \\
\hline $\begin{array}{l}\text { Field as center } \\
\text { of dialogue and } \\
\text { discussion }\end{array}$ & $\begin{array}{l}\text { Hoffman; } \\
\text { Zietsma; } \\
\text { Winn. }\end{array}$ & $\begin{array}{l}\text { Debate for } \\
\text { Thematic Interest }\end{array}$ & $\begin{array}{l}\text { Made up of organizations with often different goals, who recognize each other } \\
\text { as participants of one same discussion concerning specific topics, as well as those } \\
\text { focused on reproducing institutional practices or arrangements referring to the } \\
\text { question. }\end{array}$ \\
\hline $\begin{array}{l}\text { Field as arena } \\
\text { of power and } \\
\text { conflict }\end{array}$ & $\begin{array}{l}\text { Vieira; } \\
\text { Carvalho; } \\
\text { Misoczky. }\end{array}$ & $\begin{array}{l}\text { Domination and } \\
\text { Position Power }\end{array}$ & $\begin{array}{l}\text { Field as result of dispute to dominate it, in dynamics established by the (re) } \\
\text { allocation of actors power resources and by their position in relation to other } \\
\text { actors. }\end{array}$ \\
\hline $\begin{array}{l}\text { Field as } \\
\text { institutional } \\
\text { sphere of interests } \\
\text { under dispute }\end{array}$ & $\begin{array}{l}\text { Fligstein; } \\
\text { Swedberg; } \\
\text { Jepperson. }\end{array}$ & $\begin{array}{l}\text { Power and } \\
\text { Cognitive } \\
\text { Structures }\end{array}$ & $\begin{array}{l}\text { Constructions produced by organizations which detain power, which influence } \\
\text { the rules of interaction and dependence in the field according to their interests, } \\
\text { which, in turn, reflect their position in the social structure. }\end{array}$ \\
\hline $\begin{array}{l}\text { Field as structured } \\
\text { network of } \\
\text { relationships }\end{array}$ & $\begin{array}{l}\text { Powell; } \\
\text { White; } \\
\text { Owen-Smith. }\end{array}$ & $\begin{array}{l}\text { Structural } \\
\text { Articulation }\end{array}$ & $\begin{array}{l}\text { Specially networks of interaction, normally more integrated and intertwined, } \\
\text { which emerge as structured and structuring environments for organizations and } \\
\text { individuals, revealed by topological and structural cohesion studies. }\end{array}$ \\
\hline
\end{tabular}

CHART 1 - Field analysis perspectives

Source: Machado-Da-Silva, Guarido Filho and Rossoni (2010, p. 162)

"Both visions are jointly necessary for the development of a dynamic assessment of organizations" (ASTLEY, VEN, 2005, p. 67), due to the objective and subjective nature of organizational phenomena. This combination proposed in the article involves a concept of field in a multiparadigmatic perspective, as proposed by Machado-da-Silva, Guarido Filho and Rossoni (2010), in which control and homogeneity are effectively involved.

\section{I Institutional isomorphism}

The central proposition of contemporary institutional theories is in the understanding of structural changes, not by efficiency or competition, but by other factors that make organizations similar (CALDAS, FACHIN, 2005). The central question posed by DiMaggio and Powell (2005) is: what makes organizations so similar? The authors claim that rational actors make their organizations increasingly similar when transforming them, also calling them isomorphic.
The theoretical roots of this perspective come from the work of Meyer and Rowan (1991), Institutionalized organizations: formal structure and the myth ceremony, which aroused the interest of several authors in sociology to explain the symbolic roles of formal structures. This line of the sociology of organizations received contributions from other areas of thought such as political science and economics. Thus, the new institutionalism became an interdisciplinary theoretical arena.

New institutionalism is also made up of three different analytical perspectives: sociological institutionalism, historical institutionalism and rational choice institutionalism (HALL, TAYLOR, 1996). In these three different perspectives, the authors explore the set of relationships between institutions and their behavior, as well as the explanation of the processes through which organizations arise or change.

The work of Scott (1995) illustrates the three levels of analysis of the new institutionalism: the regulative, the normative and the cognitive, understood through their respective isomorphic 
mechanisms: coercive (rules, laws and penalties), normative (certification and acceptance) and mimetic (predominance and isomorphism). These three analytical levels allow for the understanding of different aspects of the same phenomenon (MACHADO-DA-SILVA, GONÇALVES, 1998). Organizations are embedded in fields made up by similar organizations, which are becoming increasingly similar - isomorphic within these organizational fields (DIMAGGIO, POWELL, 2005).

Coercive isomorphism results from both formal and informal pressures by certain organizations over others (DIMAGGIO, POWELL, 2005). These pressures occur through coercion, persuasion or even invitation. At this level of analysis, the legal environment affects behavior and structures of organizations and "increasingly reflects rules that are institutionalized and legitimated by the state and within the state" (DIMAGGIO, POWELL, 2005, p. 78). The result of this process makes organizations more homogeneous as a result of institutional conformation.

Mimetic isomorphism involves the environment's degree of uncertainty, encouraging imitation amongst actors. Certain organizations are taken as models, as a way of dealing with the uncertainty and ambiguity of organizational solutions (DIMAGGIO, POWELL, 2005). This is one of the explanations for the small variation and greater homogeneity of organizations. Thus, organizations in the field copy the practices and organizational models of other legitimate or successful organizations.

Normative isomorphism involves professional entities capable of regulating, enforcing and negotiating rules and regulations according to their own interests. DiMaggio and Powell (2005) highlight two important aspects relating professionalization and isomorphism: 1) support to formal education and to the legitimization of a knowledge base of professionals in the field; and 2) networks of professionals through which new organizational models are divulged.
In this sense, the three types of isomorphism are used to support the analyzes and the processes of homogeneity between companies participating in the modular plant. Institutional isomorphism, presented in the celebrated work of DiMaggio and Powell (2005, p. 82), offers two relevant propositions that are discussed in this research: 1) "the greater the degree of dependence of one organization on another, more similar it will become to that organization in terms of structure, environment and behavioral focus"; and 2) "the higher the level of structuring of a field, the greater the degree of isomorphism". These reflections allow us to understand the processes of homogeneity within the practices of automotive organizations and also the profound process of bureaucratization, still ongoing in contemporary organizations, as pointed out by Weber (1991).

\subsection{Control capacity and social skill}

A central problem for organizations is how to preserve growth and profitability. This fact involves the ability to control the actors in a given field. Organizations, according to Fligstein (2009), deal with two types of control mechanisms: the internal, to ensure resources and coordination of the organization; and the external, to ensure stable relationships between competitors and suppliers, shareholders and also ensure the survival of the organization. Internal control is the rational-legal structure present in the bureaucracy of organizations. External controls are those in the set of relationships with other organizations; they may be formal, governed by contracts, and informal, such as trust and reciprocity.

Organizations are embedded in fields made up by other organizations. The notion of field, in the vision of Fligstein and McAdam (2012), involves the capacity for political action by powerful actors, capable of stabilizing a set of relationships in favor of their own interests. Organizations holding power influence the rules of interaction and dependence in the field according to their own interests. This reflects the relative power of their position in the social 
structure, as also mentioned by Machado-daSilva, Guarido and Rossoni (2010).

Fligstein (1996) proposes a sociological view of action in the markets, whereby the market is seen as a social structure. It is important to keep in mind that the conceptions of control change according to the coalition of hegemonic forces within a field. Thus, control capacity is closely related to the rules that produce interaction. The rules that produce social interaction are understood by Fligstein (2009) as institutions. According to the author, one of the common concerns in institutional theories is to understand the construction of local social rules, which can be understood as fields, arenas or games. Inside the fields, actors are confronted with other actors, gather and structure their actions vis-à-vis other actors.

Powerful actors within organizational fields are capable of producing rules of interaction to stabilize the situation in relation to other actors (FLIGSTEIN, 2009). According to Fligstein (2009), the stability of a field may occur through groups that impose a set of rules on other groups, through government force or through the political coalition of a group or collective action. This work focuses on the first form of stability, observing which mechanisms automakers impose on the set of car parts suppliers, and on how they do this.

The strategic behavior of actors depends on the social position they occupy within the network structure, as well as on how strategic actions are structured to meet the problems of cooperation, as highlighted by Fligstein (2009). Social skill is the ability an actor has to induce cooperation with other actors, with the aim of producing and reproducing a set of rules and stabilizing a set of relationships (FLIGSTEIN, 2009).

Both the internal and external controls that organizations establish involve formal and informal aspects (MARCH, SCHULZ, ZHOU, 2000). According to DiMaggio (1998), many New Institutionalism authors have abandoned methodological individualism and emphasized the formal and informal aspects of strategic interaction between actors. Formal and informal mechanisms reinforce one another, as mentioned by Grandori and Soda (1995), and are interdependent, as mentioned by Friedberg and Neville (1999).

In this sense, although confidence is different from control, both are complementary and support cooperative relationships. The role of trust is crucial in trade relationships, as it allows for decreasing transaction costs, establishing desirable behavior, reducing the extent of formal contacts and also facilitating the solution of disputes. Thus, confidence, control and cooperation promote certain stability in relationships and can mitigate opportunism and uncertainty. Tsui-Auch and Mollering (2010) also show how vulnerability and uncertainty in the market influence joint investments and trust, established through formal and social processes.

Accordingly, the perspectives of control and of social skills presented by Fligstein (2009, p. 47) offer two relevant propositions discussed in this research: 1) "Skilled social actors are key for the emergence of new fields. They must find a way to apply the existing rules and resources in producing local orders by convincing their supporters to cooperate and finding means of accommodation with other groups"; and 2) "Skilled social actors from responsible groups, in stable fields, use the existing resources and rules to reproduce their power". These reflections allow us to understand the processes of control and power of actors engaged in this plant from the automotive sector.

\section{RESEARCH METHODOLOGY}

The ontology of scientific research involves reflection on the broader sense of being (HOUAISS, 2001) and, according to Collins and Hussey (2005), involves understanding the nature of reality. This research can be characterized within the phenomenological paradigm, due to the subjective aspect of reality studied and from the frame of reference of the participant (COLLINS, HUSSEY, 2005). As highlighted by the authors, this perspective is opposed to positivism, in 
which reality is objective and separated from the researcher. In the phenomenological paradigm, data is full of meaning and subjective elements. In this type of research, we also chose to generate theories and tend to produce qualitative data, amongst other features pointed out by Collins and
Hussey (2005). The case study protocol contains the procedures and general rules to be followed (YIN, 2005). Accordingly, Chart 2 highlights the key features of the methodology and the main procedures of fieldwork.

\begin{tabular}{|l|l|}
\hline Type of research & Qualitative, exploratory, carried out through a case study \\
\hline Data collection technique & In-depth interview, observation and document analysis \\
\hline Main analysis categories & Cooperation and control between companies \\
\hline Types of interview & Semi-structured, with the use of interview script \\
\hline Form of collection & Recording and notes about data in field journal \\
\hline Data analysis & General analytical procedure \\
\hline
\end{tabular}

CHART 2 - Main characteristics of research methodology

Source: the authors

As for the goal, this research can be classified as exploratory and of a qualitative nature, according to the designation of Collins and Hussey (2005). Exploratory and qualitative study is appropriate when situations analyzed are contemporary, comprehensive and complex; focus is greater on understanding facts and not on measuring them; there are several methodological sources for evidencing facts and when you do not have control of events/behaviors of facts/ people involved in the research (YIN, 2005).

Research data was collected through interviews on the spot, following semi-structured scripts, with production directors from the automaker and suppliers. Three visits and six interviews were carried out to collect data in the automaker and in the two modular suppliers installed within the plant (in total, the consortium has seven modules, two of which were part of the data collection). Major categories covered in the interviews refer to forms of cooperation and control. Thus, three companies were studied: the automaker and two of its modular plant suppliers. This entire apparatus of primary and secondary data was relevant to collecting and analyzing the results.

Data collection visits, observations and interviews allowed for an understanding of the division of labor and coordination of companies for vehicle assembly. The semi-structured script allowed for the explanation of the interviewee's "vision of the world" and a greater degree of depth in research questions. Data collection was also carried out through document analysis, internal processes, reports and observation. Interviews were recorded and significant and subjective observations were registered in a field diary. The field diary contains objective and subjective data observed in companies, as a way to triangulate the interview data and observed data. The interviews, the diary and the documents allowed us to assemble a great deal of information that was later categorized when analyzing results. Results analysis was carried out using the general analytical procedure, according to the designation of Collins and Hussey (2005). The general analytical procedure involves creating codes and categories of analysis for subsequent analysis of an existing theory or a new theory.

Through analysis of the results we found many subsidies from institutional theory to explain certain issues, such as the homogeneity of practices and social skills. In this way, analysis categories were then prepared, as shown in Charts 3 and 4. So, there is an inductive and later deductive relationship in the logic of building these categories, as observed by Eisenhardt (1989). In order to increase the reliability of the 
study, collected data was compared amongst the various actors and also with the other documents collected.

\section{I Modular suppliers}

Auto parts supplier 1 is engaged in the field of high-tech electronics and mechatronics; it has approximately 50,000 employees in 34 countries worldwide and a network of centers of expertise for development and production. Auto parts supplier 1 is a Brazilian subsidiary, with headquarters in Germany, and operates in assembling components/electronic and mechatronic systems. Currently, the group in Brazil consists of about a thousand employees, with an annual turnover of approximately 300 million reais.

Auto parts supplier 2 is the only one with fully national capital that is present in the plant. It was established in 1918, when the group began its activities in the lumber business in Rio Grande do Sul. It later diversified its activities over time tp the financial sector and, subsequently, to the industrial sector. From the 1990s on, auto parts supplier 2 centralized its operations in the industrial sector in the auto parts and railway equipment fields. Both have an assembly unit in the modular plant belonging to the automaker.

\subsection{Modular plant}

In a modular plant, the entire vehicle is fully assembled by modular suppliers, which are installed in the automaker's plant. These suppliers assemble the following parts: cabin, inside cabin (seats, windows, tapestry), paint, chassis, suspension, wheels and engine. As reported by interviewees, around 1000 companies applied to join the project. So there was indeed a lot of interest from companies to participate in this factory somehow, because obvious gains in know-how concerning manufacturing and product design had been verified, as well as the commercial gains implicit in these relationships.

The automaker has an effective quality control system for final products assembled by suppliers. It also acquires components for modular suppliers, which are responsible for controlling the logistics and quality of second-tier suppliers (they deliver components for the automaker's modular suppliers). Of the 1,800 employees at the plant, about 300 belonged to the assembler when data was collected.

The modular plant also simplifies the complexity of the product, increases control of suppliers, combines standardization with customization of goods and a reduction in the lead time of production (VAN HOEK, WEKEN, 1998). A significant part of materials and components used by modular suppliers in the assembly of trucks and buses is purchased by the automaker, for tax purposes and due to its bargaining power with suppliers. However, logistics coordination and the quality control of components are the responsibility of modular suppliers.

These features illustrate how the automaker was able to establish a modern factory, with reduced costs and risks, a select group of global suppliers and lower complexity of coordination of the supply chain, through a collective project with support and investment from major global suppliers. From its installation to the present day, the automaker has enjoyed an excellent division of the truck market in Brazil. Over the following topics we will highlight the main research results and final considerations.

\section{CONTROL, SOCIAL SKILL AND INSTITUTIONAL ISOMORPHISM}

The set of rules and standards that control the behavior of actors within the modular plant is large. Suppliers are involved in the structures of dense and cohesive relationships (UZZI, 1997). Modular suppliers are structurally and relationally "closer", generating strong ties between companies, according to the designation by Granovetter (2009, p. 39). These rules operate as a cognitive framework for the behavior of actors. This characteristic of the structure and the relationships in this plant generates more control 
in terms of partners' behavior and cooperation. It is in compliance with Powell (1990), who states that the more dense and cohesive a network, the greater the control of actors' behavior. This generates governance structures that are distinct from market relationships or from vertical integration in the modular plant.

Although control structures are present, at the same time we notice the automaker's capacity for agglutination and coordination when selecting and inserting suppliers in its plant so as to assemble its vehicles. This capacity, here called social skill, involves convincing and cooption of other actors to invest and cooperate within a new logic of production (FLIGSTEIN, 2009). This social skill can also be thought of in terms of the capital needed for coordinating different companies for vehicle assembly. This coordination depends on the skill of managers to coordinate separate companies and still ensure good levels of productivity.

In section 4.1 we present how this governance structure has given rise to normative, coercive and mimetic isomorphism, and how the standardization of practices between participating companies occurs. In section 4.2, we analyze the main control mechanisms implemented in the routines and in coordination amongst companies in the modular plant, in order to understand how social skill was important to unite and impose a set of controls for the stability of relationships. Both research outlines share the idea of how economic action and outcomes are embedded in the social structure.

\section{I Isomorphism and institutional order}

Control between modules led to a standardization of production practices, called coercive, normative and mimetic isomorphism (DIMAGgIO, POWELL, 1991). This standardization is a way to control the behavior of productive actors and creates a new institutional order. Coercive isomorphism occurs when the automaker imposes a set of operational requirements, performance contracts and systems capable of homogenizing the behavior of suppliers. Chart 3 shows the types of isomorphism, its analysis categories and features observed in field research.

Normative isomorphism occurs due to constant exchange and interaction amongst professionals from different organizations and cultures. Professionals are subject to isomorphic processes, as are organizations. Training, practices, operational processes and constant meetings between executives from the modules and the automaker lead companies to an imitation of structure, behavior and especially organizational practices.

\begin{tabular}{|l|l|l|}
\hline & $\begin{array}{l}\text { Analysis } \\
\text { categories }\end{array}$ & Observed features \\
\hline $\begin{array}{l}\text { Coercive } \\
\text { isomorphism }\end{array}$ & $\begin{array}{l}\text { Rules, laws and } \\
\text { sanctions }\end{array}$ & $\begin{array}{l}\text { Imposition by automaker of a set of operational requirements, performance systems and } \\
\text { contracts capable of homogenizing the behavior of suppliers in terms of maintaining quality } \\
\text { and performance levels. Suppliers have to meet similar rules and tend to develop coercive } \\
\text { isomorphism in the plant. For example: quality practices were all standardized between modules. }\end{array}$ \\
\hline $\begin{array}{l}\text { Normative } \\
\text { isomorphism }\end{array}$ & $\begin{array}{l}\text { Certification and } \\
\text { acceptance }\end{array}$ & $\begin{array}{l}\text { Normative isomorphism occurs due to constant exchange and interaction amongst professionals } \\
\text { from different organizations and cultures. To be completely assembled, the vehicle needs high } \\
\text { integration between companies, leading to the exchange of information and knowledge. For } \\
\text { example: daily meetings occur between auditors and module managers and employees. }\end{array}$ \\
\hline $\begin{array}{l}\text { Mimetic } \\
\text { isomorphism }\end{array}$ & $\begin{array}{l}\text { Predominance } \\
\text { and mimetism }\end{array}$ & $\begin{array}{l}\text { System that elects best practices by one of the modules. If that module was chosen as reference, } \\
\text { all other modular suppliers must adopt the same practice. This idea of standardizing practices } \\
\text { generates a cognitive framework for social actors. For example: human resources systems were } \\
\text { all standardized between participating companies. }\end{array}$ \\
\hline
\end{tabular}

CHART 3 - Types of isomorphism, its analysis categories and features observed in the field.

Source: the authors. 
Mimetic isomorphism occurs when the automaker creates a method of electing the best practices by each modular supplier, through which all other suppliers should adopt the same practice. The adoption of such practices has led to the high level of standardization and homogeneity of practices and routines amongst suppliers in the modular plant. As the automaker's production manager said, "in the beginning it was hard. Nowadays you don't know what belongs to whom, because it's all been very standardized... practices were incorporated and now nothing has to be changed, because the best of everyone is here. But there's a lot from each one." Uncertainty is an important source for imitation, as stated by DiMaggio and Powell (2005). The automaker, in electing the best practices and standardizing them across modular suppliers, reduced the potential uncertainties, ambiguities and variations in the productive system. Thus, the automaker's imposing of a set of operational requirements and performance systems leads to homogeneous rules and also cognitive frameworks and to a certain combination of coercive and mimetic isomorphism.

This standardization at reported levels allows for the greater predictability of suppliers' behavior and also confirms the following proposition by DiMaggio and Powell (2005, p. 82): the greater the degree of dependence of one organization on another, more similar it will become to that organization in terms of structure, environment and behavioral focus". The same as in the modular plant, the automaker is dependent of only seven modules for vehicle assembly and therefore to a stage of high reliance on suppliers. The high degree of dependence of the automakers on its suppliers stimulated processes of cooperation and control.

Cooperative relations eventually establish rules of trust, predictability of relationships and long-term contracts between the actors (BURT, 1992). Similarly, Coleman (1988) emphasized that cooperative relationships promote trust, cooperation, reciprocity and also greater social control amongst its members. The search for higher levels of efficiency in modular plants is marked by the ability to control and the hegemoneity of procedures.

The automaker introduced a new coordination structure capable of maintaining control and stability of the supply structure; at the same time, it reduced uncertainty and investments for the launch of the new plant. The launch of a production plant always involves marketing, political and institutional uncertainty and high investments. In this way, the organizational design of the automaker mitigated uncertainties and investments, combining a good deal of delegation of assembly activities while developing structures for interorganizational control.

The adopted model also affects significantly the homogenization of practices and competing priorities, such as: cost, quality, flexibility and deadlines, through operating agreements with parts suppliers. Modular suppliers also have to meet a wide range of demands and also often have to deal with problems with suppliers of second and third levels, because all the coordination of logistics and quality is the responsibility of suppliers. Establishing mechanisms of control and standardization allows the automaker to enjoy a stable institutional structure and greater predictability of transactions.

The modular plant must be seen based on the set of relations and exchange of resources between actors, as reported in other studies. Doran (2004) states that in the modular system there is a transfer of value added by the automaker to the first tier suppliers, mainly modular suppliers. Similarly, Morris, Donnelly and Donnelly (2004) show that in the modular system there is mutual development between automaker and suppliers to accept working methods, standard procedures, rules, documents and communication methods.

Institutional structuring occurs, according to DiMaggio and Powell (2005), with increasing interaction between organizations; the emergence of structures of domination; increasing load of information and the development of a mutual awareness amongst participants. In this sense, the deployment of the modular plant led to a process of structuring the field through those relationships and confirms the other proposition 
of DiMaggio and Powell (2005, p 84.): "The higher the level of structuring of a field, the greater the degree of isomorphism". However, the types of isomorphisms observed are not mechanically (deterministically) derived from the "structure" established by the automaker. There is interaction space for companies to trade experiences and this stimulates isomorphism. In this sense, structuring occurs not as a cause and effect relationship, but as a process.

This new structural configuration allowed the automaker to become a "parent" of the various productive activities carried out by the modules. However, suppliers, in several testimonies, highlight that they acquired more technical and managerial knowledge and more decisionmaking power within the production process. This knowledge was produced collectively and led to high coercive, mimetic and normative isomorphism amongst participating companies.

The modular plant stimulated competitive isomorphism in the projects of new plants by other competing automakers, which moved on to similar systems. These practices used in the modular plant became a reference amongst competing automakers, encouraging a degree of competitive isomorphism between companies. Reflections of this nature can help understand the levels of dependence and homogeneity of a given field of activity on certain actors.

\subsection{Social skill and control}

The control of behavior in pursuit of high levels of cooperation is one of the main mechanisms for dealing with dependence on suppliers and achieving high levels of cooperation. Only control, however, is not enough to guarantee results; as well as control, a lot of dialogue between assembler and suppliers is necessary to coordinate various activities amongst companies for vehicle assembly. This capacity to agglutinate, co-opt, control and coordinate other actors is called by Fligstein (2009) social skill, and involves the skill of an actor to induce cooperation with other actors, with the aim of producing and reproducing a set of rules and stabilizing a set of relationships. Thus, according to the designation of Fligstein (2009), the automaker showed a great "social skill" when deploying the modular system, in order to motivate, select and coordinate those partners for vehicle assembly.

In all factory decisions there must be a consensus between the automaker and its modular suppliers. If there is no consensus, the issue has to be voted by the seven modular suppliers and the automaker, which has the final vote. The director himself reported that he lost power with the new system and that decisions are much more shared (if the seven modular suppliers are against the controversial decision by the automaker, such as overtime, it will go to vote). In this case, negotiation, as decision-making, was included in companies' day to day activities - and the supply of systems and modules has raised several reflections on the division of "forces" in the global auto industry.

Scholars share the assumption that there has been a possible increase in the power of decision and negotiation of auto parts suppliers over recent years (HELPER, 1991). As one of the managers of the modules said, "the director cannot act concerning operational employees, cannot send away a guy who disobeys", because the employee's contractor is the modular supplier and not the automaker. As reported by another module manager, "exactly, in the end we end up being the rule because of this technological condition ... if we understand that from the point of view of quality or logistics a certain supplier must be removed from the chain, we have power of influence with the automaker to veto it or strengthen it". This power increase is related to the assembly activities carried out by modular suppliers and the more participatory nature of the contract. This fact lends a paradox to the plant, presented in the organizational studies of communication and coordination, according to Motta and Vasconcelos (2002). In this paradox, the greater communication due to the complexity of assembly in the modular plant generates greater difficulty in coordinating and in the capacity to exercise power, even in formal contracts.

Regarding the ability to coalesce, as reported, at the launch of the factory 1000 candidate suppliers attended, willing to participate 
in the modular plant, of which 7 modules were chosen for the assembly of vehicles. The inclusion of a supplier at this level of transaction is highly restricted by the level of skills and requirements required by the automaker. Chart 4 illustrates forms of control and social skills and forms of reproducing the field.

\begin{tabular}{|c|c|c|}
\hline & $\begin{array}{l}\text { Analysis } \\
\text { categories }\end{array}$ & Observed features \\
\hline Social skill & $\begin{array}{l}\text { Cooptation and } \\
\text { convincing to } \\
\text { agglutinate and } \\
\text { coordinate }\end{array}$ & $\begin{array}{l}\text { The social skill of the automaker is observed when convincing suppliers, using rules and } \\
\text { resources, to invest and cooperate in a new production logic. It is a way of applying existing rules } \\
\text { and resources in the production of local orders. Social skills are also present in the coordination } \\
\text { activities of the plant, where negotiation and decisions are shared. }\end{array}$ \\
\hline Control system & $\begin{array}{l}\text { Formal and } \\
\text { informal control }\end{array}$ & $\begin{array}{l}\text { Control mechanisms instituted make up a set of rules, norms and sanctions. The level of control } \\
\text { of the automaker on the suppliers goes from formal mechanisms to informal mechanisms, } \\
\text { such as trust, reciprocity, commitment. Formal mechanisms are in contracts and performance } \\
\text { measurement systems and the informal are subjectively in daily work relationships between } \\
\text { companies of the plant. }\end{array}$ \\
\hline $\begin{array}{l}\text { Field } \\
\text { reproduction }\end{array}$ & $\begin{array}{l}\text { Status and } \\
\text { legitimacy }\end{array}$ & $\begin{array}{l}\text { The automaker, by proposing operation in a modular plant, instituted a new system of production } \\
\text { and supply. The automaker thus "simplifies" the number and complexity in coordinating the } \\
\text { supply system of the plant. Thus, due to the level of outsourcing, the plant becomes a reference } \\
\text { for other automakers, with a high level of status and legitimacy. }\end{array}$ \\
\hline
\end{tabular}

CHART 4 - Control, social skill and field e reproduction

Source: the authors.

The social skill exercised by the automaker confirms the proposition of Fligstein (2009) on the creation of fields: "Skilled social actors are key for the emergence of new fields. They must find a way to apply the existing rules and resources in producing local orders by convincing their supporters to cooperate and finding means of accommodation with other groups" (FLIGSTEIN, 2009, p. 70). The automaker used social skills when convincing suppliers, using rules and resources, to invest and cooperate within a new logic of production; social skills, however, involves a more voluntaristic and less deterministic logic of action. To sustain this form of coordination with modular suppliers, the automaker created this "governance regime" that forces the dialogue in the plant's coordination and daily activities. This form of governance promotes negotiation and dialogue. In this case, the market can be understood as a political process, as pointed out by Fligstein (1996), and comprises the performance of companies through various mechanisms to control the market, because stable markets reflect hierarchical positions in the field.
Suppliers were also co-investors in the modular plant, when buying the equipment to begin plant operation. The automaker, as a strategic actor, negotiated, highlighted its intentions, sought out a collective solution and imposed a new order under its power, as termed by Fligstein (2009).

The degree of control that the automaker has on its suppliers is quite evident. All established control mechanisms make up a set of rules and standards, which make more predictable the relationships between automakers and auto parts. Evidently, intense relationships enable a wider range of control tasks and penalties. The degree of control of the automaker on suppliers results goes from formal mechanisms to informal mechanisms. As highlighted by Grandori and Soda (1995), besides the existence of formal coordination mechanisms, consortia employ intense social coordination, where several informal mechanisms of coordination and control such as trust, reciprocity, commitment are present. Thus, informal mechanisms operate as coexisting with formal mechanisms to control opportunism and 
at the same time facilitate the flow of knowledge (HELPER, MACDUFFIE; SABEL, 2000). But it should be noted that the interdependence brought into play in this arrangement leads to the establishment of formal mechanisms, but which are not sufficient for the coordination of the plant. Thus, the high degree of control found in modular plant confirms another proposition concerning rules and resources: "skilled social actors from responsible groups, in stable fields, use the existing resources and rules to reproduce their power" (FLIGSTEIN, 2009, p. 70).

The fields give actors chances of reproducing advantages precisely because there is unequal distribution of resources and rules (FLIGSTEIN, 2009). The automaker, by proposing operation in a modular plant, instituted a new system of production and supply. Suppliers had to undertake activities in coordinating secondtier suppliers related to quality and logistics. The automaker thus "simplifies" the number and complexity of coordination in the supply system of the plant and improves its position in the field as to its major competitors.

The rules in the field can be formal and informal. Formally, the automaker controls suppliers through six mechanisms: production schedule, compliance with the program, quality indicators, process audits, inventory control and tracking defects. These control mechanisms are recorded and analyzed daily via information technology. According to the production manager: "this is the easiest part because everything is in software... in my folder I have control of all the factories and not only of this one ... so you have control over quality, processes, production, volume, productivity and human resources". According to the interviewee, daily negotiations are the most complex activities. The high degree of interdependence explains the complexity of negotiations with suppliers, who expanded decision-making power. The plant has all the controls of a "traditional" automaker; however, in the modular plant, the automaker controls rates carried out by suppliers and not of employees and internal departments. The production costs of a traditional factory become transaction costs in modular plants.

The automaker controls all information about labor, investments, losses, and other information. This control provides the automaker with maneuver margins for negotiations. The production manager gave an example: "if one of the modules requests an increase (in value) of its parts, I have all the information to check the need for an increase". As the automaker's production manager said, "...I have to know how his labor is, what he needs to invest, how his production is, his losses... ... at the end of the month, we take all these indicators and analyze how many percent each module reached."

Another control mechanism are the rigorous audits carried out by the automaker. Audits, carried out daily, represent a great power of control over suppliers. All the modules know who failed to meet goals. If the vehicle is not approved by the audit, the automaker pays no modular supplier. Thus, as exemplified by the production manager, "one module speaks to the other: look, your 60\% harmed me and I did not get paid". Thus, besides formal coercive control audits, there is also an informal normative control between modules in order to maintain high levels of productivity. This is in agreement with the statement of Hollingswortth and Boyer (1997), who highlight the existence of forms of coordination, through which collective actors control each other. In the modular plant, as well as formal control, there are ways of control between suppliers themselves, understood in literature as self enforcement. This type of control is present in the informal aspects of relationships between suppliers and the automaker. In this sense, formal and informal controls are combined and coexist effectively in relationships with automakers with modular suppliers.

Informal aspects also interfere in the automaker's ability to control suppliers. These informal aspects, as significant as control mechanisms, include trust, relationships, exchanges, friendships in the context and organizational dynamics of the plant, also confirmed in studies by Lazzarini (2008). There 
is, in the modular plant, trust between the parties. As the production manager mentioned, "the contract never had to be the basis for a decision or demand", because the actors established relationships of trust and commitment.

Commitment between actors is also very evident, according to the observations conferred in data collection. Thus, people and companies involved present significant levels of cooperation and commitment, according to data collection and field observations. As mentioned by one of the managers of the modules, "confidence is gained over time, through actions, through situations - and this has been the basic premise of the relationship of companies within the plant". $\mathrm{He}$ also says: "Automaker executives have access to strategic business information. These instruments are established here, business meetings... So access to this level of information reflects the utmost confidence in this relationship and the confidence level is much higher now compared to when we started this plant". Another module manager also says: "You provide schedules, information and a range of plans; if you have no confidence, even if you surround yourself with documents, the relationship becomes impossible."

These informal aspects help in the predictability and control of behavior and are also related to cultural and identity frameworks. This perspective helps in understanding the stability and in the transformation of the fields, in which powerful actors create and control other actors through explicit and implicit rules and impose a new system of control and domination.

\section{FINAL CONSIDERATIONS}

The behavior of actors is associated with a set of rules and standards within the processes of trade between organizations. The starting point of this level of analysis opposes research that sees organizational decisions as something unilateral, individual and atomistic, without considering the social mechanisms within trade processes. Due to this fact, the relationship between individuals (agency) and social structure is an important discussion within sociological and organizational theory (ABERCROMBIE, HILL, TURNER, 2000; MACHADO-DA-SILVA, GUARIDO, ROSSONI, 2010, p. 4), since it retrieves the discussion of how structure establishes, supports and limits the actions and choices of economic actors.

In this sense, the article contributes to reconciling the institutional approaches to understanding both homogeneity (isomorphism), permeating everyday practices (DIMAGGIO, POWELL, 2005), as well as the social skill of the automaker in bringing together other companies to support its organizational project (FLIGSTEIN, 2009). Thus, this research contributes to one of the key debates in organizational theory for understanding the nature of economic action resulting from the social structure of companies and from the capacity of the agency (ASTLEY, VEN, 2005).

This article proposed an analysis of how isomorphism and the ability to control supports a cohesive and stable coordination structure in a modular plant. We conclude that the automaker employs highly institutionalized mechanisms and routines that are capable of controlling and standardizing the behavior and performance of the parts suppliers. These mechanisms are not limited only to the formal aspects of the relationship, but also to its informal aspects (relationships, trust, rules etc.) that are capable of institutionalizing many of the production practices in that arrangement.

We found in this research that skilled social actors, such as the automaker, look for ways to apply existing rules and resources when producing local orders, and use them to reproduce power and convince other actors to cooperate in the case of this study, modular suppliers. This aspect illustrates how this social skill can be built by organizations that are more powerful or less so to raise funds and information. This result thus confirms the proposition of Fligstein (2009): "Skilled social actors are key for the emergence of new fields. They must find a way to apply the existing rules and resources in producing local orders by convincing their supporters to cooperate 
and finding means of accommodation with other groups" and "skilled social actors from responsible groups, in stable fields, use the existing resources and rules to reproduce their power".

The survey also revealed that the degree of dependence of one organization on another (automaker and suppliers) stimulates high levels of coercive, normative and mimetic isomorphism. In this way, it endorses the proposals highlighted by DiMaggio and Powell (2005) and Fligstein (2009). It is also consistent with the density of the relationship network and isomorphism, since the higher the density the greater the isomorphism. This result also confirms the following propositions enunciated by DiMaggio and Powell (1991, p.76): "the greater the degree of dependence of one organization on another, more similar it will become to that organization in terms of structure, environment and behavioral focus" (DIMAGGIO, POWELL, 1991, p.76) and "the higher the level of structuring of a field, the greater the degree of isomorphism".

Despite the risks involving the highly cooperative relationships that are present in the modular plant, none of the modular suppliers chose to withdraw from it after the five-year contract. Such relationships imply collective gains for actors who have a prominent position in the structure of relationships. An interesting aspect is that many suppliers of this plant began to offer similar services to those of other automakers and industrial parks in Brazil, generating the process called by DiMaggio and Powell (2005) competitive isomorphism between plants (since many then adopted similar assembly systems, called industrial parks). These suppliers have developed another way to make profits, still taking on greater responsibilities in assembling and managing materials for the supply of modules and/or systems in various plants in Brazil.

The automaker created institutional conditions of stability in the supply and installation of modules and vehicles. These rules and formal and informal mechanisms of interaction control part of the relationship with the upstream market (here referring to suppliers). As highlighted by Fligstein (2009), the goal of these mechanisms is to control the sources of instability in markets and create favorable conditions for growth and survival. From a competitive standpoint, the automaker in the study achieved significant results in the division of the market from the modular plant on.

Thus, the modular plant is an organizational project with relative success in the ability to generate stability in the set of relationships with suppliers, through formal and informal coordination mechanisms. This allowed the automaker to share risks, investments and also establish long-term relationships with its suppliers. According to the concept highlighted by Fligstein (2009), the automaker presents high levels of social skills through an institutional structure (formal and informal mechanisms), capable of inducing other actors to cooperation.

As Pfeffer and Salancik (1982) explain:

(1) organizations are the basic units of analysis for understanding inter-company relationships; (2) these organizations are not autonomous, but rather are limited by a network of relationships with other organizations; (3) interdependence, when combined with uncertainty about the actions of actors, leads to a situation in which survival and success are uncertain, so (4) organizations proceed in order to deal with external interdependencies, although its actions are never completely successful and still produce new dependence structures. Moreover, (5) these dependence structures stimulate the emergence of interorganizational power. Resource dependence proposed by Pfeffer and Salancik (1982) and research by Hollingswortth and Boyer (1997) has made a significant contribution to the study of fields by involving the idea of a political actor dealing with dependencies and forms of control. Thus, powerful actors can build political coalitions and patterns of field domination, as stated by DiMaggio and Powell (1991) and Fligstein (2009).

A very clear issue is that automakers have become more interdependent on auto parts suppliers with parks and modular consortium. Whether for reasons of codesign, asset specificity, joint investments, partnerships, technological 
strategies or financial resources; so automakers are more dependent on their suppliers, especially those which introduced industrial parks or the modular system. Within this type of arrangement, the decision-making process depends entirely on the supplier, especially in the modular consortium. The decision process is nonetheless a power resource and also a method of investigation of power (BOBBIO, MATTEUCCI; PASQUINO, 1995). In the modular consortium and industrial parks there is a greater division of labor between the actors, stimulating the division of resources, especially technological and organizational ones. Automakers are increasingly dependent on the know-how of auto parts suppliers, especially facing the tendency of systems to becoming black box. The increase in know-how by these suppliers is also closely linked to the reconfiguration of power in the automotive sector. These suppliers have power resources in different situations and the automaker has to deal with this dependence and with the power "games" in the field. This requires more social skill from automakers to coordinate the entire assembly system and the adjacent processes of negotiation and decision.

To Fligstein (1996), the success of the idea of control will depend on the skill of managers of large companies in building new solutions for the current crisis. Still according to the author, structural change require increased cooperation between companies in order to create new technologies, to make pressure in favor of changes in antitrust laws; in this context, the managers of these companies have to cope with resource dependencies, with macro institutional pressures, with organizational legitimacy and a host of other high complexity issues. This aspect supports how the automaker created a stable institutional framework for the coordination of suppliers and the assembly of the vehicle. Similarly, Hatch (1997) argues that managers create solutions (contracts, co-optation, control, productive and technological cooperation, partnerships, relationships based on trust, copying, mergers, acquisitions etc.) to reduce the dependence of their organizations on scarce resources, through existing structures of interorganizational control.
By incorporating a deterministic perspective and a voluntaristic one, this article points to new ways of understanding control and hegemoneity in coordination processes. Intentional interdisciplinarity between a political perspective of control, as highlighted by Fligstein (2009), and a sociological one, as highlighted by DiMaggio (1998), seeks to construct and deconstruct bridges from distinct theoretical contributions. In this respect, Hatch (1997) mentions the process of deconstruction that happens while bridges and discussions of different perspectives are built, allowing for the systematization and redirection of analytic bases in organizational studies. Far from closing the topic, there is still a field to be built in research concerning the control capacity and homogeneity amongst organizations.

\section{REFERENCES}

ABERCROMBIE, N.; HILL, S.; TURNER, B. S. The penguin dictionary of sociology. England: Peguin Books, 2000.

ABRAMOVAY, R. Desenvolvimento e instituições: a importância da explicação histórica. In: ARBIX, G.; ZILBOVICIUS, M.; ABRAMOVAY, R. (Orgs.). Razóes e ficçóes do desenvolvimento. São Paulo: Unesp; Edusp, 2001. Chapt. 8, p. 165-177.

ASTlEY, W. G.; VEN, A. H. V. Debates e perspectivas centrais na teoria das organizações. Revista de Administraçáo de Empresas, Rio de Janeiro, v. 45, n. 2, p. 52-73, Apr./Jun. 2005.

BOBBIO, N.; MATTEUCCI, N.; PASQUINO, G. Dicionário de Política. Brasília: Editora UNB, 1995.

BOURDIEU, P. Social structure of the economy. New York: John Wiley, 2005.

BURT, R.S. Structural holes: the social structures of competition. Cambridge: Harvard University Press, 1992. 
CALDAS, M. P.; FACHIN, R. C. Paradigma funcionalista: desenvolvimento de teorias e institucionalismo nos anos 1980 e 1990 . Revista de Administraçáo de Empresas, Rio de Janeiro, v. 45, n. 2, p. 46-51, Apr./Jun. 2005.

CASTRO, R. B.; BALDI, M. Inovação no Polo Joalheiro de Belém: uma análise a partir do mecanismo de imersão estrutural. Cadernos EBAPE, Rio de Janeiro, v. 8, n. 3, p. 492-513, Sept. 2010.

COLEMAN, J. S. Social capital in the creation of human capital. American Journal of Sociology, Chicago, v. 94, p. 95-120, 1988. Supplement.

COllins, J.; HuSsey, R. Pesquisa em administração. Porto Alegre: Bookman, 2005.

DIMAGGIO, P. J. The new institutionalism: avenue of collaboration. Journal of Institutional and Theoretical Economics, Tuebingen, v. 154, n. 4, p. 696-705, Dec. 1998.

; POWELL, W. W. A gaiola de ferro revisitada: isomorfismo institucional e racionalidade coletiva nos campos organizacionais. Revista de Administraçáo de Empresas, Rio de Janeiro, v. 45, n. 2, p. 74-89, Apr./Jun. 2005.

. The iron cage revisited: institutional isomorphism and collective rationality in organization fields. In: POWELL, W. W.; DimagGiO, P. J. (Orgs.). The new institutionalism in organizational analysis. Chicago: University of Chicago Press, 1991. Chapt. 3, p. 63-82.

DORAN, D. Rethinking the supply chain: an automotive perspective. Supply Chain Management: An International Journal, [S. 1.], v. 9, n. 1, p. 102-109, 2004.

EISENHARDT, K. M. Building theories from case study research: academy of management. Academy of Management Review, Briarcliff Manor, v. 14, n. 4, p. 532, Oct. 1989.

FLIGSTEIN, N. Habilidade social e a teoria dos campos. In: MARTES, A. C. B. (Org.). Redes e sociologia econômica. São Carlos: Edufscar, 2009. p. 69-106.

Markets as politics: a political-cultural approach to market institutions. American Sociological Review, Washington, v. 61, n. 4, p. 656-673, Aug. 1996.

; McADAM, D. Theory of fields. New

York: Oxford University Press, 2012.

FRIEDBERG, E.; NEVILLE, J. P. Inside partnership: trust, opportunism and cooperation in the european automobile industry. In: GRANDORI, A. (Ed.). The game of network. London: Routledge, 1999. p. 67-88.

GNYAWALI, D.; MADHAVAN, R. Cooperative networks and competitive dynamics: a structural embeddedness perspective. Academy of Management Review, Briarcliff Manor, v. 26, n. 3, p. 431-445, 2001.

GOMES, J. P. P.; VIEIRA, M. M. F. O campo da energia elétrica no Brasil de 1880 a 2002. Revista de Administraçáo Pública, Rio de Janeiro, v. 43, n. 2 , p. 295-321, Mar./Apr. 2009.

GUARIDO FILHO, E. R.; MACHADO-DASILVA, C. L. The development of institutional theory in the field of organization studies in Brazil. Cadernos. EBAPE, Rio de Janeiro, v. 8, n. 2, p. 278-301, Jun. 2010.

GRANDORI, A.; SODA, G. Inter-firm networks: antecedents, mechanisms and forms. Organization Studies, Berlin, v. 16, n. 2, p. 183-214, Mar. 1995.

GRANOVETTER, M. S. Ação econômica e estrutura social: e o problema da imersão. In: MARTES, A. C. B. (Org.). Redes e sociologia econômica. São Carlos: Edufscar, 2009. Chapt. 1, p. 31-68.

HATCH, M. J. Organization theory. New York: Oxford University Press, 1997. 
HALL, P. A.; TAYLOR, R. C. Political science and the three new institutionalisms. Political Studies, [S. 1.], n. 44, n. 6, p. 936-957, Dec. 1996.

HELPER, S. How much has really changed between U.S. automakers and their suppliers? Sloan Management Review, Cambridge, Summer, v. 32, n. 4, p. 15-28, 1991.

; MACDUfFIE, J. P.; SABEL, C. Pragmatic collaborations: advancing knowledge while controlling opportunism. Industrial and Corporate Change, Oxford, v.9, n.3, p. 443-487, Sept. 2000.

HIRSCH, P. M. Been there, done that, moving on: reflections on institutional theory's continuing evolution. In: GREENWOOD, R. et al. (Eds.). The SAGE handbook of organizational institutionalism. London: SAGE, 2008. p. 783-789.

. Sociology without social structure: neoinstitutional theory meets brave new world. American Journal of Sociology, Chicago, v. 102, n. 6, p. 1702-1723, May, 1997.

HOLLINGSWORTH, J. R.; BOYER, R. Contemporary capitalism. Cambridge: Cambridge University Press, 1997.

HOUAISS, A. Dicionário Houaiss da língua portuguesa. Rio de Janeiro: Objetiva, 2001.

LAZZARINI, S. G. Empresas em rede. São Paulo: CENGAGE Learning, 2008.

LIN, J. L. et al. Network embeddedness and technology transfer performance in $\mathrm{R} \& \mathrm{D}$ consortia in Taiwan. Technovation, [S.1.], v. 29, n. 11, p.763-774, Nov. 2009.

MACHADO-DA-SILVA, C. L.; GONÇALVES, S. A. A teoria institucional (nota técnica). In: CLEGG, S. R.; HARDY, C.; NORD, W. R. (Orgs.). Handbook de estudos organizacionais. São Paulo: Atlas, 1998. v. 1, p. 220-226.
; GUARIDO FILHO, E. R.; ROSSONI, L. Campos organizacionais: seis diferentes leituras e a perspectiva de reestruturação. Revista de Administração Contemporânea, Curitiba, v.14, Sept. 2010. Edição Especial.

MAINELA, T.; PUHAKKA, V. Embeddedness and networking as drivers in developing an international joint venture. Scandinavian Journal of Management, Oxford, v. 24, n. 1, p. 17-32, Mar. 2008.

MARCH, J. G.; SHULTZ, M.; ZHOU, X. The dynamics of rules: change in written organizational code. Stanford: Stanford University Press, 2000.

MEYER, J. W.; ROWAN, D. C. Institutionalized organizations: formal structure as myth and cerimony. In: POWELL, W. W.; DIMAGGIO, $P$. J. The new institutionalism in organizational analysis. Chicago: University of Chicago Press, 1991. p. 41-62.

MORRIS, D.; DONNELLY, T.; DONNELLY, T. Suppliers parks in the automotive industry. Supply Chain Management: an International Journal, [S. 1.], v. 9, n. 2, p. 129-133, 2004.

MOTTA, F. C. P.; VASCONCELOS, I. F. G. Teoria geral da administraçáo. São Paulo: Thomson: 2002.

PFEFFER, J.; SALANCIK, G. R. The external control of organizations: a resource dependence perspective. New York: Harper \& Row, 1982.

POWELL, W. W. Neither market nor hierarchy: network forms of organizations. Research in Organizational Behavior, [S. 1.], v. 12, p. 295336, 1990.

SCOTT, W. R. Institutions and organization. London: Sage Publications, 1995.

SMELSER, N. J.; SWEDBERG, R. The sociological perspective on the economy. In: ; (Eds.). The handbook of 
economic sociology. Princeton, New Jersey: Princeton University Press, 1994. p. 3-26.

SWEDBERG, R. The toolkit of economic sociology. CSES Working Paper Series, n. 22. Ithaca: Cornell University, 2004.

TSUI-AUCH, L. S.; MÖLLERING, G. Wary managers: unfavorable environments, perceived vulnerability, and the development of trust in foreign enterprises in China. Journal of International Business Studies, Basingstoke, v. 41, n. 6, p. 1016-1035, Aug. 2010.

UZZI, B. The sources and consequences of embeddness for the economic performance of organizations: the network effect. American Sociological Review, Washington, v. 61, n. 4, p. 674-698, Aug. 1996.

Social structure and competition in interfirm networks: the paradox of embeddedness. Administrative Science Quartely, [S.1.], v. 42, n. 1, p. 35-67, Mar. 1997.

VALE, G. M. V.; GUIMARÁES, L. O. Redes sociais na criação e mortalidade de empresas. Revista de Administração de Empresas, Rio de Janeiro, v. 50, n. 3, p. 325-337, Jul./Sept. 2010.
VAN HOEK, R. I.; WEKEN, H. A. M. The impact of modular production on the dynamics of supply chains. International Journal of Logistics Management, Bradford, v. 9, n. 2, p. 35-50, 1998.

VASCONCELOS, F. C. A institucionalização das estratégias de negócios: o caso das startups na internet brasileira em uma perspectiva construtivista. Revista de Administraçáo Contemporânea, Curitiba, v. 8, n. 2, p. 159-179, Apr./Jun. 2004.

WEBER, M. Economia e sociedade: fundamentos da sociologia. Brasília: Editora UnB, 1991.

YAMIN, M.; ANDERSSON, U. Subsidiary importance in the MNC: what role does internal embeddeness play? International Business Review, [S.1.], v. 20, n. 2, p. 151-162, Apr. 2011.

YIN, R. Estudo de caso planejamento e métodos. Porto Alegre: Bookman, 2005.

ZUKIN, S.; DIMAGGIO, P. Structures of capital. Cambridge: Cambridge University Press, 1990 . 